\title{
SIFAT KAYU JATI UNGGUL NUSANTARA (Tectona grandis L.f.) PADA TIGA KELAS DIAMETER POHON
}

\author{
The nature of jati unggul nusantara (Tectona grandis L.f.) wood in three classes of tree \\ diameter
}

\author{
Gudiwidayanto Sapto Putro 1 , Sri Nugroho Marsoem², Joko Sulistyo ${ }^{3}$ dan Suryo Hardiwinoto ${ }^{3}$ \\ ${ }^{2}$ Kontributor Utama, ${ }^{1}$ Institut Pertanian Intan Yogyakarta, \\ Jl. Magelang KM 5,6 Sleman, Yogyakarta, Indonesia \\ email penulis korespondensi: snmarsoem@ugm.ac.id \\ 2,3Universitas Gadjah Mada, \\ Jl. Agro No 1 Bulaksumur, Sleman, Yogyakarta, Indonesia
}

Tanggal diterima: 28 April 2020, Tanggal direvisi: 28 April 2020, Disetujui terbit: 10 Juni 2020

\begin{abstract}
Increasing the growth rate of teak trees is carried out to shorten the tree harvest rotation and reduce the deficit of teak timber supply, while maintaining the superiority of wood properties. The study was conducted to determine the nature of five-year-old JUN Teak wood in three classes of tree diameter and radial position of the trunk. This study arranged in a completely randomized design with factorial combinations of the treatments of radial positions and diameter classes consisting of large $(18-22 \mathrm{~cm})$, medium $(14-18 \mathrm{~cm})$ and small $(10-14 \mathrm{~cm})$ stem diameters, and the radial position of wood on the trunk based on the tree's ring. Three trees were felled for each stem diameter class, totally nine trees were used in this study. The testing of the physical properties of wood and the measurement of fiber dimensions were conducted using British Standards 373 and the IAWA method, respectively. The results showed that the diameter of the tree and the radial position of the wood had a significant effect on fiber thickness, fiber length, and physical properties of wood. The tree growth rate had a negative correlation with fiber length (-0.67), fiber wall thickness (-0.65), air-dry moisture content (-0.91) and air dry specific gravity (-0.86), and had a positive correlation with fiber diameter (0.61) and green water content (0.78). According to the pattern of wood properties in the radial direction, JUN wood harvested at the age of five was categorized as juvenile wood. This wood is acceptable as furniture and lightweight construction material.
\end{abstract}

Keywords: fiber dimension, fiber thickness, fiber length, physical properties, radial position of the trunk

\begin{abstract}
ABSTRAK
Peningkatan pertumbuhan pohon jati dilakukan untuk menurunkan daur panen sehingga dapat mengurangi defisit pasokan kayu jati dengan tetap mempertahankan keunggulan sifatnya. Penelitian dilakukan untuk mempelajari sifat kayu Jati Unggul Nusantara umur lima tahun pada tiga kelas diameter pohon dan posisi radial batang. Perlakuan penelitian disusun dalam rancangan acak lengkap secara faktorial untuk perlakuan kelas diameter yang terdiri dari diameter batang besar $(18-22 \mathrm{~cm})$, sedang $(14-18 \mathrm{~cm})$ dan kecil $(10-14 \mathrm{~cm})$, serta posisi radial kayu pada batang berdasar lingkaran tahun pohon. Setiap kelas diameter batang diwakili oleh tiga pohon sampel yang masing-masing diuji sifat fisik kayu menggunakan Standar British 373 dan dimensi serat menggunakan metode IAWA. Hasil penelitian menunjukkan perbedaan kelas diameter batang berpengaruh nyata terhadap tebal serat, panjang serat, dan sifat fisik kayu. Posisi radial kayu berpengaruh nyata terhadap dimensi serat, kadar air kayu, dan berat jenis kering udara. Laju pertumbuhan pohon memiliki korelasi negatif dengan panjang serat $(-0,67)$, ketebalan dinding serat $(-0,65)$, kadar air kering udara $(-0,91)$ dan berat jenis kering udara $(-0,86)$, serta memiliki korelasi positif dengan diameter serat $(0,61)$ dan kadar air segar $(0,78)$. Menurut pola sifat pada arah radial, kayu JUN yang dipanen pada usia lima tahun masih termasuk kayu juvenil. Kayu ini memenuhi syarat digunakan sebagai bahan baku furniture dan konstruksi ringan.
\end{abstract}

Kata kunci: dimensi serat, tebal serat, panjang serat, sifat fisik kayu, posisi radial batang

\section{PENDAHULUAN}

Jati (Tectona grandis L.f.) merupakan salah satu jenis pohon tropis terpenting di Indonesia. Jenis ini telah ditanam secara luas terutama di pulau Jawa oleh Perhutani, bahkan mulai dikembangkan di luar Jawa. Sifat kayunya yang kuat, awet, mudah dikerjakan, serta memiliki penampilan yang indah menyebabkan kayu jati dikenal sebagai kayu 
yang bernilai tinggi (Lacret et al., 2012; Lukmandaru, 2011; Marsoem et al., 2014). Selama ini tanaman jati diketahui memiliki pertumbuhan lambat dengan rotasi panen 60 hingga 80 tahun (Jha, 2016; Perhutani-B, 2019). Kebutuhan kayu jati yang terus meningkat, sementara ketersediaannya terus berkurang (Perhutani-A, 2019), telah mendorong usaha menambah ketersediaan dengan mempercepat pertumbuhan pohon jati.

Pertumbuhan batang pohon merupakan akumulasi dari pembentukan kayu dan kulit kayu hasil pembelahan jaringan meristem. Pertumbuhan yang dihasilkan oleh aktivitas meristem sekunder menghasilkan pertambahan diameter pohon (Shmulsky \& Jones, 2019). Oleh karena itu diameter pohon, selain tinggi (pohon), merupakan indikator penting dalam pengukuran pertumbuhan pohon (Mugasha et al., 2013; Sumida et al., 2013). Pertumbuhan pohon pada sejumlah spesies selama satu musim pertumbuhan tahunan menghasilkan lapisan yang disebut lingkaran pertumbuhan yang memiliki perbedaan sifat antara kayu yang dihasilkan pada awal dan akhir musim pertumbuhan (Shmulsky \& Jones, 2019). Teknologi pemuliaan pohon diterapkan pada pohon agar menghasilkan pertumbuhan yang lebih cepat dengan bentuk batang yang baik (silindris dan lurus) seperti halnya Jati Unggul Nusantara (JUN). Sejauh ini, JUN telah ditanam di berbagai daerah dengan tingkat pertumbuhan lebih cepat, batang lurus dan bulat. Pada sisi lain, perhatian penting ditujukan tidak hanya pada peningkatan pertumbuhan pohon hutan, tetapi juga pada sifat kayu yang dihasilkannya (Karlinasari et al., 2018). Beberapa penelitian pada sejumlah kayu tropis tidak menunjukkan adanya pengaruh laju pertumbuhan terhadap sifat kayunya (Kojima, Yamamoto, Okumura, et al., 2009; Naji et al., 2012; Pertiwi et al., 2017). Meskipun begitu, peningkatan laju pertumbuhan pada tanaman jati dilaporkan menyebabkan perubahan sifat kayunya (Marsoem et al., 2014; Rizanti et al., 2018; Zahabu et al., 2015). Hingga saat ini informasi mengenai pertumbuhan JUN maupun sifat kayu yang dihasilkan masih sangat terbatas.

Keragaman sifat kayu selain terjadi antar jenis dan individu pohon, juga terjadi di dalam individu pohonnya sendiri. Perbedaan sifat ini biasanya terkait dengan pengaruh faktor lingkungan dan pendewasaan kambium (Shmulsky \& Jones, 2019), yang menyebabkan perbedaan sifat kayu pada kedudukan radial. Hasil penanaman JUN di beberapa wilayah memperlihatkan pertumbuhan diameter batang yang berbeda, walaupun pada tempat tumbuh yang sama. Studi mengenai sifat kayu jati unggul dilakukan pada tiga kelas diameter pohon dan perbedaan posisi radial kayu. Hasil penelitian ini diharapkan dapat mendukung optimalisasi pemanfaatan kayu dari jenis cepat tumbuh khususnya kayu JUN.

\section{BAHAN DAN METODE}

Penelitian ini dilakukan pada pohon jati JUN dari tegakan umur lima tahun yang tumbuh di hutan rakyat di Kecamatan Panjatan, Kabupaten Kulonprogo, Daerah Istimewa Yogyakarta, Indonesia, $7^{\circ}$ 54'49,3 "LS dan $110^{\circ} 10^{\prime} 19,0 " B T$.

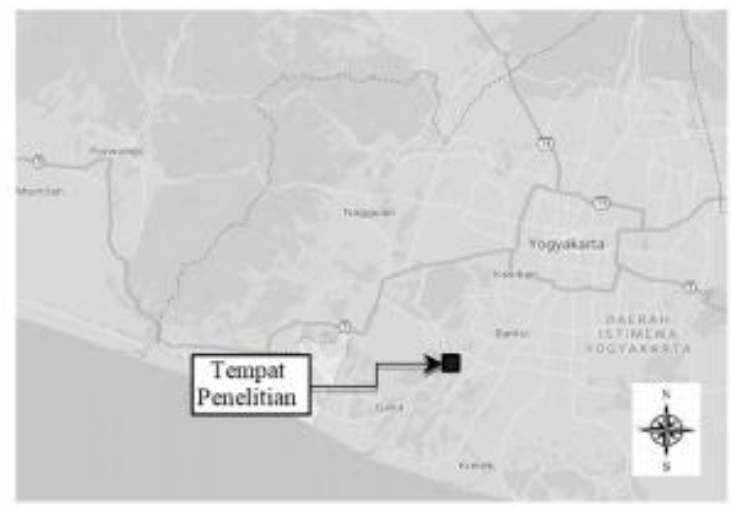

Gambar 1. Lokasi tegakan Jati Unggul Nusantara di Kecamatan Panjatan, Kabupaten Kulonprogo, Daerah Istimewa Yogyakarta, Indonesia (7 ${ }^{\circ}$ 54'49,3 "S; $110^{\circ} 10^{\prime} 19,0^{\prime \prime} \mathrm{E}$ )

Desain penelitian mengenai sifat kayu ini menggunakan rancangan acak lengkap dengan dua faktor perlakuan yang disusun secara faktorial. Faktor pertama adalah kelas diameter pohon yang diklasifikasikan menjadi diameter 
besar $(18-22 \mathrm{~cm})$, sedang $(14-18 \mathrm{~cm})$ dan kecil $(10-14 \mathrm{~cm})$. Faktor kedua adalah posisi radial berdasarkan lingkaran tahun pohon (R1=merupakan lingkaran tahun pertama/dekat empulur, .... R5= lingkaran tahun terakhir/dekat kulit). Setiap unit perlakuan diulang tiga kali sehingga digunakan sembilan sampel pohon penelitian. Setiap sampel pohon ditebang dan dari potongan batang setinggi dada $(1,3 \mathrm{~m}$ dari pangkal batang) dibuat cakram (disk) dengan ketebalan dua $\mathrm{cm}$. Setiap cakram dibuat dua potongan sampel pada arah utara batang, yaitu satu potong dengan lebar dua $\mathrm{cm}$ untuk pengujian sifat fisika kayu dan potongan lain dengan lebar satu $\mathrm{cm}$ untuk pengukuran dimensi serat kayu. Pengujian sifat fisika kayu yang meliputi kadar air dan berat jenis mengikuti standar British (British-Standard, 1957) yang dimodifikasi sesuai dengan ukuran sampel yang dapat diperoleh. Pengukuran dimensi serat kayu menggunakan metode IAWA (IAWA, 2008). Data dan hasil pengamatan dianalisis menggunakan analisis varian. Sumber variasi yang menunjukkan hasil signifikan, dilakukan uji lanjut dengan Duncan's multiple range test (DMRT). Analisis korelasi digunakan untuk menentukan hubungan antar sifat kayu yang relevan. Koefisien korelasi dihitung dengan rumus:

$r_{x y}=\frac{n \sum x_{i} y_{i}-\left(\sum x_{i}\right)\left(\sum y_{i}\right)}{\sqrt{\left\{n \sum x_{i}{ }^{2}-\left(\sum x_{i}\right)^{2}\right\}-\left\{n \sum y_{i}{ }^{2}-\left(\sum y_{i}\right)^{2}\right\}}}$

Keterangan:

$r_{x y} \quad=$ Koefisien korelasi pearson

$x_{i} \quad=$ Variabel independen

$y_{i} \quad=$ Variabel dependen

$n \quad=$ Banyak sampel

\section{HASIL DAN PEMBAHASAN}

Rekapitulasi analisis varians dari pengukuran diameter serat dan pengujian sifat fisik kayu JUN ditampilkan pada Tabel 1.

Hasil analisis varian menunjukkan bahwa perbedaan kelas diameter berpengaruh secara signifikan terhadap dimensi serat (kecuali diameter serat). Sementara itu posisi radial kayu berpengaruh secara signifikan terhadap dimensi serat dan sifat fisik kayu yang diamati. Interaksi kedua perlakuan tidak menunjukkan pengaruh yang signifikan terhadap semua sifat kayu yang diamati.

Tabel 1. Rekapitulasi hasil analisis varian masingmasing sifat kayu

\begin{tabular}{|c|c|c|c|c|}
\hline Parameter & Diameter & Radial & Interaksi & $\mathbf{r}^{2}$ \\
\hline Panjang serat & $0,024^{* *}$ & $0,060^{* *}$ & 0,003 ns & 0,708 \\
\hline Diameter serat & $0,289 \mathrm{~ns}$ & $23,033^{* * *}$ & $0,817^{\text {ns }}$ & 0,834 \\
\hline Tebal dinding sel & $4.165^{\text {** }}$ & $0,359 *$ & $0,300^{\text {ns }}$ & 0,885 \\
\hline KA segar & $860,216^{*}$ & 529,186 * & $74,403^{\text {ns }}$ & 0,609 \\
\hline KA kering udara & $0,413 *$ & $1,717 * *$ & $0,256^{\text {ns }}$ & 0,735 \\
\hline Berat jenis & $0,013^{* *}$ & 0,044 * & 0,001 ns & 0,667 \\
\hline Catatan: $* *$ & $\begin{array}{l}\text { Igat } \\
\text { signi } \\
\text { hasi }\end{array}$ & $\begin{array}{l}\text { nifikan; } \\
\text { an; } r^{2}\end{array}$ & $\begin{array}{l}*=\text { sign } \\
=\mathrm{ko}\end{array}$ & $\begin{array}{l}\text { xan; } \\
\text { sien }\end{array}$ \\
\hline
\end{tabular}

\section{A. Panjang serat}

Tabel 2 menunjukkan bahwa perbedaan kelas diameter dan posisi radial berpengaruh secara signifikan terhadap panjang serat. Hasil uji lanjut menunjukkan bahwa panjang serat meningkat dari pohon dengan kelas diameter besar ke kelas diameter kecil, tetapi panjang serat yang dihasilkan oleh pohon kelas diameter sedang dan kecil tidak berbeda nyata. Dari aspek ini peningkatan kecepatan pertumbuhan sampai pada batas tertentu dapat tidak berdampak pada pengurangan panjang serat kayu yang dihasilkan.

Tabel 2. Rerata panjang serat $(\mathrm{mm})$ dan lebar lingkaran tahun $(\mathrm{cm})$ berdasarkan posisi radial dan kelas diameter

\begin{tabular}{cccccc}
\hline \multirow{2}{*}{ Radial } & \multicolumn{3}{c}{ Diameter } & Rerata & $\begin{array}{c}\text { L1t } \\
\text { (cm) }\end{array}$ \\
\cline { 2 - 5 } & Besar & Sedang & Kecil & & a \\
\hline R1 & 0,801 & 0,768 & 0,857 & $0,809^{\mathrm{a}}$ & 2.0 \\
R2 & 0,851 & 0,970 & 0,914 & $0,912^{\mathrm{b}}$ & 1,5 \\
R3 & 0,899 & 0,982 & 0,975 & $0,952^{\mathrm{b}}$ & 1,3 \\
R4 & 1,041 & 1,063 & 0,942 & $1,015^{\mathrm{c}}$ & 1,4 \\
R5 & 0,982 & 1,098 & 1,116 & $1,065^{\mathrm{c}}$ & 1,0 \\
\hline Rerata & $0,895^{\mathrm{x}}$ & $0,976^{\mathrm{y}}$ & $0,981^{\mathrm{y}}$ & Kor.ps-1lt $^{2}=-0,67$ \\
\hline
\end{tabular}

Catatan: Angka yang diikuti dengan huruf yang sama di setiap faktor menunjukkan tidak berbeda nyata; Kor.= nilai korelasi, ps = panjang serat, llt= lebar lingkaran tahun 
Pada arah radial terjadi peningkatan panjang serat secara signifikan setiap dua tahun pertumbuhan, kecuali pada awal pertumbuhan (lingkaran tahun pertama). Hasil ini mirip dengan hasil yang dilaporan pada kayu jati yang tumbuh di Gunungkidul (Marsoem et al., 2014) maupun pada tegakan jati alam di Timor Timur (Cardoso et al., 2015).

Serat kayu JUN yang dihasilkan dari lingkaran tahun keempat (umur empat tahun) dan kelima (umur lima tahun) secara berturutturut sama dan lebih panjang dari serat kayu jati unggul JPP berusia 7 tahun yaitu 1,015 mm (Basri \& Wahyudi, 2013). Panjang serat ini hampir sama dengan serat JPP berusia 9 tahun yaitu 1,150 mm (Wahyudi \& Arifien, 2005). Perbedaan hasil ini erat kaitannya dengan kondisi tempat tumbuh serta sifat genetis dari pohon jati yang ditanam. Hasil ini mengindikasikan bahwa pohon JUN, yang merupakan hasil pengembangan dari jati unggul JPP, pada umur yang lebih muda telah mampu menghasilkan sifat kayu yang sama baik dengan JPP.

Peningkatan panjang serat yang terjadi sampai umur lima tahun menunjukkan bahwa sampai umur tersebut pohon masih menunjukkan perkembangan menuju kayu dewasa yang dikenal sebagai kayu juvenil (Gryc et al., 2011; Lachenbruch et al., 2011; Shmulsky \& Jones, 2019). Hasil ini seperti yang dilaporkan sebelumnya bahwa proporsi kayu juvenil tanaman jati sampai usia 20 tahun masih berkisar $80-100 \%$ tergantung pada laju pertumbuhan (Bhat et al., 2001). Penurunan panjang serat seiring dengan pertambahan diameter pohon serta hasil analisis korelasi antara laju pertumbuhan dan panjang serat dengan nilai $r=-0,67$ menunjukkan penurunan laju pertumbuhan akan diikuti oleh peningkatan panjang serat. Hasil penelitian ini tidak seperti yang dilaporkan sebelumnya bahwa pertambahan panjang serat berbanding lurus dengan laju pertumbuhan (Anish et al., 2015; Missanjo \& Matsumura, 2016). Sementara hasil penelitian lain melaporkan bahwa laju pertumbuhan tidak berpengaruh nyata terhadap perubahan panjang serat (Malik \& Abdelgadir, 2015). Perbedaan kecenderungan ini mengindikasikan besarnya pengaruh spesies, individu pohon maupun tempat tumbuh terhadap karakteristik kayu yang dihasilkan (Shmulsky \& Jones, 2019).

\section{B. Diameter serat}

Tabel 3 menunjukkan rerata diameter serat sebesar 18,8 $\mu \mathrm{m}$. Diameter serat cenderung turun dari lingkaran tahun dekat empulur (lingkaran tahun pertama) ke arah bagian dekat kulit kayu (lingkaran tahun terakhir), sementara itu diameter serat lebih cenderung meningkat dari pohon berkelas diameter kecil ke besar. Diameter serat terbesar diperoleh di lingkaran tahun bagian dalam kelas diameter besar. Diameter serat terkecil diperoleh di lingkaran luar pohon berkelas diameter kecil.

Tabel 3. Rerata diameter serat $(\mu \mathrm{m})$ berdasarkan posisi radial dan kelas diameter

\begin{tabular}{ccccc}
\hline \multirow{2}{*}{ Radial } & \multicolumn{3}{c}{ Diameter } & \multirow{2}{*}{ Rerata } \\
\cline { 2 - 4 } & Besar & Sedang & Kecil & \\
\hline R1 & 21,2 & 20,1 & 21,1 & $20,8^{\mathrm{a}}$ \\
R2 & 19,8 & 19,8 & 20,2 & $19,8^{\mathrm{ab}}$ \\
R3 & 19,0 & 18,4 & 18,6 & $18,7^{\mathrm{b}}$ \\
R4 & 17,4 & 18,0 & 16,8 & $17,4^{\mathrm{c}}$ \\
R5 & 17,1 & 17,5 & 16,5 & $17,1^{\mathrm{c}}$ \\
\hline Rerata & 18,9 & 18,7 & 18,6 & Kor.ds-llt $=0,61$ \\
\hline
\end{tabular}

Catatan: Angka yang diikuti dengan huruf yang sama di setiap faktor tidak berbeda nyata; ds = diameter serat, llt = lebar lingkaran tahun yang mengacu pada Tabel 2

Hasil analisis varian menunjukkan bahwa posisi radial kayu berpengaruh signifikan terhadap diameter serat yang dihasilkan, tetapi kelas diameter batang dan interaksi keduanya tidak berpengaruh signifikan. Hasil uji lanjut menunjukkan hasil dalam pola yang bertentangan dengan variabilitas panjang serat. Penurunan diameter serat terlihat dari lingkaran tahun dekat empulur hingga lingkaran tahun dekat kulit kayu. Penurunan diameter serat pada arah radial (seiring bertambahnya umur pohon) mengindikasikan peningkatan kualitas kayu 
untuk tujuan utama pemanfaatan kayu JUN sebagai bahan konstruksi dan mebeler. Hasil ini juga memperkuat indikasi bahwa pohon JUN masih dalam periode menghasilkan kayu muda/juvenil, merujuk pada kemiripan karakter kayu yang dihasilkan pada periode awal pertumbuhan pohon (Shmulsky \& Jones, 2019). Hasil yang berbeda dilaporkan terjadi pada Alnus glutinosa (Kiaei et al., 2016). Sebaran diameter serat berkorelasi positif dengan laju pertumbuhan $(\mathrm{r}=0,61)$. Ini berarti $61 \%$ peningkatan laju pertumbuhan akan diikuti oleh peningkatan diameter serat. Dalam aspek ini, peningkatan laju pertumbuhan akan berdampak kurang baik terhadap sifat kayu JUN sebagai bahan baku konstruksi dan furnitur, karena akan menurunkan berat jenis kayu. Korelasi ini tidak seperti yang dilaporkan pada Gmelina arborea (Fo \& Roque, 2007) atau pada Populus nigra (Efhamisisi et al., 2016).

\section{Tebal dinding serat}

Nilai tebal dinding serat yang ditampilkan pada Tabel 4 menunjukkan peningkatan tebal dinding serat secara konsisten dari pohon dengan kelas diameter besar ke kelas diameter kecil. Peningkatan tebal dinding serat juga terjadi dari kayu dekat empulur (lingkaran tahun pertama) ke arah kulit kayu (lingkaran tahun terakhir).

Tabel 3. Rerata diameter serat $(\mu \mathrm{m})$ berdasarkan posisi radial dan kelas diameter

\begin{tabular}{ccccc}
\hline \multirow{2}{*}{ Radial } & \multicolumn{3}{c}{ Diameter } & \multirow{2}{*}{ Rerata } \\
\cline { 2 - 4 } & Besar & Sedang & Kecil & \\
\hline R1 & 21,2 & 20,1 & 21,1 & $20,8^{\mathrm{a}}$ \\
R2 & 19,8 & 19,8 & 20,2 & $19,8^{\mathrm{ab}}$ \\
R3 & 19,0 & 18,4 & 18,6 & $18,7^{\mathrm{b}}$ \\
R4 & 17,4 & 18,0 & 16,8 & $17,4^{\mathrm{c}}$ \\
R5 & 17,1 & 17,5 & 16,5 & $17,1^{\mathrm{c}}$ \\
\hline Rerata & 18,9 & 18,7 & 18,6 & Kor.ds-llit $=0,61$ \\
\hline
\end{tabular}

Catatan: Angka yang diikuti dengan huruf yang sama di setiap faktor tidak berbeda nyata; ds = diameter serat, llt = lebar lingkaran tahun yang mengacu pada Tabel 2

Hasil analisis varian menunjukkan bahwa kelas diameter pohon dan posisi radial kayu dalam batang berpengaruh signifikan terhadap ketebalan dinding serat, seperti yang dilaporkan sebelumnya pada kayu jati (Hidayati et al., 2014; Wahyudi et al., 2014). Hasil uji lanjut menunjukkan bahwa serat paling tebal diperoleh dari posisi lingkaran tahun keempat hingga kelima (dekat dengan kulit kayu). Peningkatan tebal dinding sel secara progresif dari empulur menuju kulit mengindikasikan sifat kayu juvenil dengan ciri dinding sel tipis pada awal pertumbuhan dan bertambah dengan cepat ke bagian luar batang (Shmulsky \& Jones, 2019). Sementara itu, hasil analisis korelasi menunjukkan bahwa terdapat hubungan yang bertolak belakang antara laju pertumbuhan dengan ketebalan dinding serat. Peningkatan laju pertumbuhan $65 \%$ akan menurunkan ketebalan serat. Nilai korelasi tersebut termasuk tinggi (Sugiyono, 2013). Seperti halnya dengan diameter serat kayu, peningkatan laju pertumbuhan akan menghasilkan kayu yang semakin kurang menguntungkan dalam pemanfaatannya sebagai bahan konstruksi. Selain fraksi lumen, ketebalan dinding sel sangat menentukan kerapatan kayu (Zieminska et al., 2014). Hasil ini tidak seperti yang pernah dilaporkan bahwa peningkatan laju pertumbuhan secara signifikan meningkatkan tebal dinding serat (Malik \& Abdelgadir, 2015).

\section{Kadar air}

Hasil pengukuran kadar air segar (Tabel 5) menunjukkan bahwa kadar air segar kayu JUN berkisar 109-139\%. Rerata kadar air segar adalah adalah 122,58\%. Tingginya kisaran kadar air segar ini masih dalam kisaran kadar air segar kayu secara umum yaitu $\geq 100 \%$ (Shmulsky \& Jones, 2019). Kadar air ini hampir sama dengan kadar air segar klon jati dari India yang mencapai kisaran 117-137\% (Shukla \& Viswanath, 2014), tetapi lebih tinggi dari hasil penelitian pada tegakan jati (Basri \& Wahyudi, 2013; Marsoem et al., 2014). Tingginya kadar air segar kayu berdampak kurang menguntungkan dalam proses pengangkutan dan potensi serangan organisme perusak kayu. 
Kadar air cenderung turun dari pohon berkelas diameter besar hingga kecil. Pola ini juga terjadi mulai lingkaran tahun pohon dekat empulur (lingkaran tahun pertama) ke arah kulit (lingkaran tahun pohon terakhir) menyerupai diameter serat kayu.

Hasil analisis varian menunjukkan adanya pengaruh yang nyata dari perbedaan posisi radial dalam batang maupun kelas diameter batang. Kecenderungan penurunan kadar air dari empulur ke arah bagian kulit menunjukkan rongga sel yang lebih sedikit pada lingkaran tahun dekat kulit kayu. Hal ini didukung hasil pengamatan yang menunjukkan turunnya diameter serat seperti ditampilkan pada Tabel 3 sedangkan ketebalan dinding serat meningkat dari lingkaran tahun pertama ke lingkaran kelima seperti ditampilkan pada Tabel 4. Peningkatan tebal dinding dan penurunan diameter serat menjelaskan pola sebaran berat jenis pada arah radial yang dilaporakan pada kayu jati di hutan rakyat Gunungkidul (Marsoem et al., 2014).

Tabel 5. Kadar air segar (\%) berdasarkan posisi radial dan kelas diameter.

\begin{tabular}{ccccc}
\hline \multirow{2}{*}{ Radial } & \multicolumn{3}{c}{ Diameter } & \multirow{2}{*}{ Rerata } \\
\cline { 2 - 4 } & Besar & Sedang & Kecil & \\
\hline R1 & 139,47 & 132,89 & 123,75 & $132,04^{\mathrm{a}}$ \\
R2 & 137,52 & 122,87 & 117,67 & $126,02^{\mathrm{ab}}$ \\
R3 & 139,52 & 121,68 & 115,20 & $125,47^{\mathrm{ab}}$ \\
R4 & 113,45 & 117,94 & 111,61 & $114,33^{\mathrm{b}}$ \\
R5 & 122,66 & 113,40 & 109,00 & $115,02^{\mathrm{b}}$ \\
\hline Rerata & $130,52^{\mathrm{a}}$ & $121,76^{\mathrm{ab}}$ & $115,45^{\mathrm{b}}$ & Kor.kas-11t $=0,78$ \\
\hline
\end{tabular}

Catatan: Angka yang diikuti dengan huruf yang sama di setiap faktor tidak berbeda nyata; Kor= Nilai korelasi; kas = kadar air segar; llt: lebar lingkaran tahun yang mengacu pada Tabel 2

Hasil analisis korelasi antara laju pertumbuhan tahunan dan kadar air segar menunjukkan klasifikasi nilai korelasi yang tinggi (Sugiyono, 2013). Nilai tersebut menunjukkan $78 \%$ peningkatan laju pertumbuhan akan diikuti oleh peningkatan kadar air kayu segar. Laju pertumbuhan pohon yang tinggi cenderung memiliki diameter serat yang lebih besar dan berdampak pada tingginya kadar air segar. Peningkatan diameter serat (Tabel 2) serta penurunan tebal dinding serat (Tabel 3) seiring peningkatan laju pertumbuhan mengakibatkan rongga sel semakin besar. Kandungan air pada kayu segar mengisi sebagian rongga sel dan dinding sel. Semakin besarnya rongga sel akan meningkatkan kemampuan menyimpan air di dalamnya (Shmulsky \& Jones, 2019).

Tabel 6. Variabilitas kadar air kering udara (\%) berdasarkan posisi radial dan kelas diameter

\begin{tabular}{ccccc}
\hline \multirow{2}{*}{ Radial } & \multicolumn{3}{c}{ Diameter } & \multirow{2}{*}{ Rerata } \\
\cline { 2 - 4 } & Besar & Sedang & Kecil & \\
\hline R1 & 14,35 & 14,84 & 15,03 & $14,74^{\mathrm{a}}$ \\
R2 & 14,89 & 15,05 & 15,14 & $15,03^{\mathrm{b}}$ \\
R3 & 15,29 & 15,3 & 15,36 & $15,32^{\mathrm{c}}$ \\
R4 & 15,52 & 15,36 & 15,71 & $15,53^{\text {cd }}$ \\
R5 & 15,94 & 14,99 & 15,92 & $15,62^{\mathrm{d}}$ \\
\hline Rerata & $15,20^{\mathrm{a}}$ & $15,11^{\mathrm{a}}$ & $15,43^{\mathrm{b}}$ Kor.kaku-1lt $=-0,91$ \\
\hline
\end{tabular}

Catatan: Angka yang diikuti dengan huruf yang sama di setiap faktor tidak berbeda nyata; kaku = kadar air kering udara; llt: lebar lingkaran tahun yang mengacu pada Tabel 2

Tabel 6 menunjukkan rata-rata kadar air kering udara kayu JUN sebesar 15,25 dengan kisaran 14,35 - 15,43\%. Peningkatan kadar air kayu terjadi dari batang kelas diameter besar ke kecil dan dari posisi kayu dekat empulur ke kulit kayu. Hasil pengukuran kadar air kayu kering udara ini termasuk tinggi. Kadar air kering udara secara umum yang berkisar 1216\% (Shmulsky \& Jones, 2019). Tingginya kadar air kering udara kemungkinan terkait dengan waktu pengukuran yang dilakukan pada bulan Nopember (musim hujan). Kelembaban udara yang tinggi berdampak pada kadar air kayu kering udara, mengacu pada sifat kayu yang higroskopis (Glass \& Zelinka, 2010; Panshin \& de Zeeuw, 1980). Hasil analisis varian menunjukkan bahwa diameter batang dan posisi kayu dalam arah radial memiliki pengaruh signifikan terhadap variasi kadar air kayu kering udara. Pada arah radial, kadar air kayu meningkat secara signifikan dari lingkaran pertama ke lingkaran kedua, setelah itu peningkatan yang nyata terjadi setiap dua tahun 
hingga tahun kelima. Tingginya kadar air kering udara pada kayu bagian batang dekat kulit besar kemungkinan terkait dengan mulai terbentuknya kayu teras pada bagian dekat empulur. Keberadaan kayu teras yang tersusun oleh selsel yang sudah tidak memiliki fungsi fisiologis kemungkinan menyebabkan kadar air kayu turun dan tidak sebesar kadar air pada bagian kayu yang masih hidup. Kayu teras dilaporkan memiliki kadar air yang lebih rendah daripada kayu gubal (Herritsch, 2007).

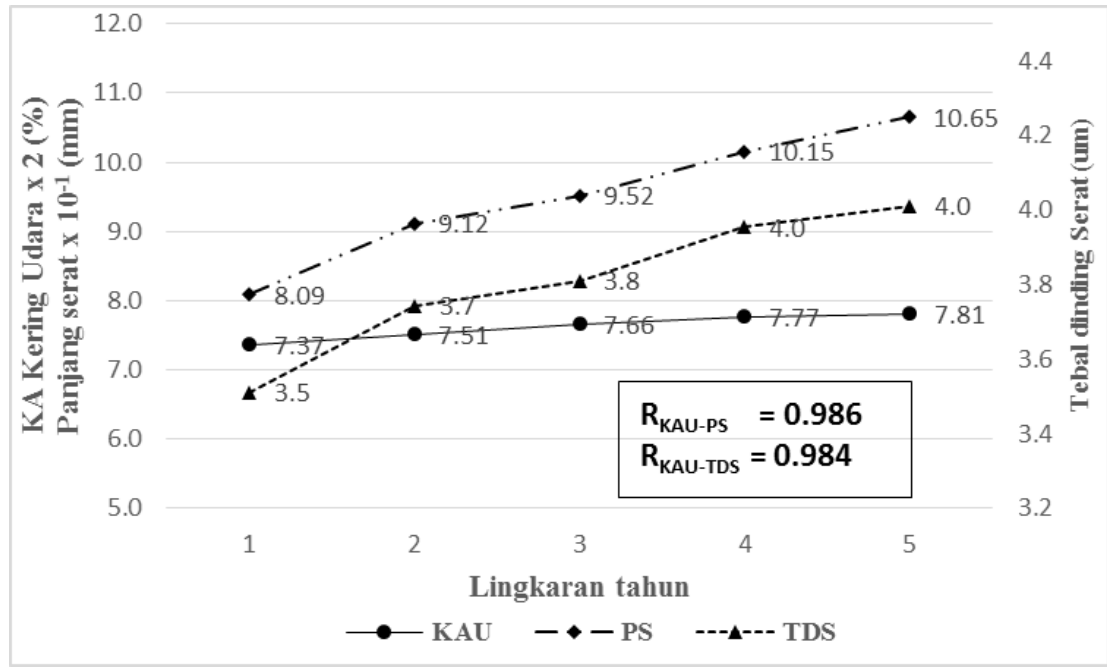

Gambar 2. Hubungan antara kadar air kering udara dengan Panjang serat dan ketebalan dinding serat. KAU = Kadar Air Kering Udara; PS = Panjang Serat; TDS = Ketebalan Dinding Serat.

Kadar air kayu dari batang berdiameter besar dan sedang tidak menunjukkan perbedaan yang signifikan, tetapi batang berdiameter kecil memiliki kadar air kayu yang secara signifikan lebih tinggi daripada keduanya. Pola ini berlawanan dengan pola variabilitas diameter serat dan kadar air segar kayu yang ditampilkan pada Tabel 3 dan Tabel 5, tetapi mirip dengan pola panjang serat dan tebal dinding serat yang ditampilkan pada Tabel 2 dan Tabel 4. Tingginya nilai korelasi seperti terlihat pada Gambar 2 mengindikasikan peran panjang serat dan tebal dinding sel dalam meningkatkan jumlah air yang mampu diikat oleh kayu.

\section{E. Berat jenis kayu}

Nilai rata-rata berat jenis kayu kering udara secara keseluruhan adalah 0,485. Pohon dengan diameter besar cenderung memiliki berat jenis yang lebih rendah dibandingkan dengan diameter kecil, sementara berat jenis cenderung meningkat pada arah radial, dari dekat empulur menuju kulit.
Tabel 7.Berat jenis kayu kering udara berdasarkan posisi radial dan kelas diameter

\begin{tabular}{ccccc}
\hline \multirow{2}{*}{ Radial } & \multicolumn{3}{c}{ Diameter } & \multirow{2}{*}{ Rerata } \\
\cline { 2 - 4 } & Besar & Sedang & Kecil & \\
\hline R1 & 0,43 & 0,43 & 0,50 & $0,453^{\mathrm{a}}$ \\
R2 & 0,45 & 0,48 & 0,51 & $0,480^{\mathrm{ab}}$ \\
R3 & 0,46 & 0,47 & 0,54 & $0,490^{\mathrm{ab}}$ \\
R4 & 0,48 & 0,50 & 0,53 & $0,503^{\mathrm{b}}$ \\
R5 & 0,48 & 0,50 & 0,51 & $0,497^{\mathrm{b}}$ \\
Rerata & $0,460^{\mathrm{a}}$ & $0,476^{\mathrm{a}}$ & $0,518^{\mathrm{b}}$ Kor.bj-1lt $=-0,86$ \\
\hline
\end{tabular}

Catatan: Angka yang diikuti dengan huruf yang sama di setiap faktor tidak berbeda nyata; bjku=panjang serat; llt= lebar lingkaran tahun yang mengacu pada Tabel 2

Berat jenis kering udara kayu JUN lebih tinggi dari berat jenis JPP umur lima tahun bahkan hampir sama dengan JPP umur tujuh tahun (Basri \& Wahyudi, 2013), serta dalam kisaran berat jenis klon jati dewasa dari Costa Rica (Arce \& Moya, 2015). Hasil ini menunjukkan keberhasilan pengembangan jati JUN baik dalam hal produktivitas volumentrik maupun kualitas kayunya. Hasil analisis varian 
menunjukkan bahwa perbedaan diameter batang dan posisi kayu dalam arah radial secara signifikan mempengaruhi variabilitas berat jenis kayu kering udara. Hasil uji lanjut menunjukkan bahwa peningkatan pertumbuhan dari diameter sedang menuju diameter besar tidak mengurangi berat jenis kayu secara nyata. Hasil ini dapat menjadi acuan dalam pengembangan sistem silvikultur dikaitkan dengan upaya mempertahankan kualitas kayunya. Pada arah radial peningkatan berat jenis terjadi secara gradual. Peningkatan secara signifikan terjadi setelah tiga sampai empat tahun pertumbuhan. Peningkatan berat jenis yang berlangsung secara gradual ini agak berbeda dengan umumnya kayu juvenil yang ditandai oleh perubahan cepat dalam karakteristik kayu, termasuk berat jenis kayu (Gryc et al., 2011; Lachenbruch et al., 2011). Peningkatan berat jenis pada posisi radial juga dilaporkan pada kayu Acacia auriculiformis (Mohamad \& Marsoem, 2007).

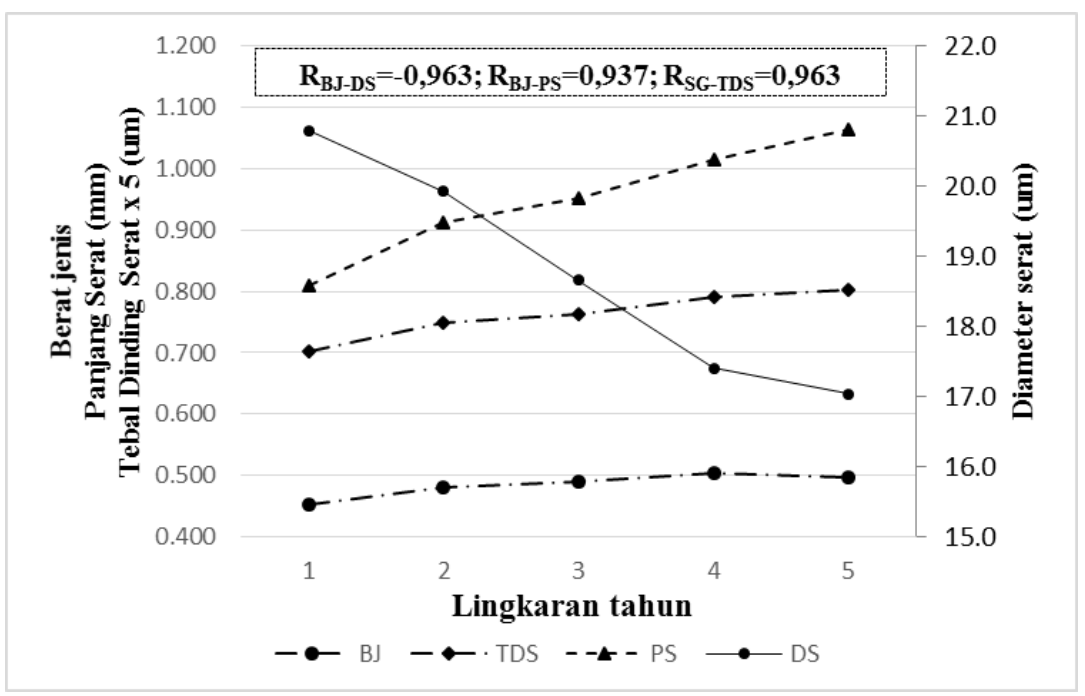

Gambar 3. Hubungan antara berat jenis kering udara (BJ) dengan diameter serat (DS), panjang serat (PS), dan tebal dinding serat (TDS).

Hasil analisis korelasi antara laju pertumbuhan dan berat jenis kayu menunjukkan $86 \%$ peningkatan laju pertumbuhan akan menurunkan berat jenis kayu. Hubungan berat jenis dan laju pertumbuhan ini juga didukung oleh hasil pengamatan pada rendahnya berat jenis kayu dari batang pohon. Hasil yang berbeda diperoleh dari studi pada kayu jati (Jayawardana \& Amarasekera, 2009) maupun pada spesies Gmelina arborea (Kojima, Yamamoto, Marsoem, et al., 2009) yang tidak menunjukkan adanya hubungan antara laju pertumbuhan dengan berat jenis kayu.

Nilai berat jenis kayu kering udara menunjukkan hubungan yang kuat dengan data lain dimensi serat (Gambar 3). Hubungan antara berat jenis dan sifat anataomi kayu juga dilaporkan pada beberapa hasil penelitian sebelumnya (Fujiwara et al., 1991; Haroen,
2017; Yudhanto \& Sulistyo, 2013; Zieminska et al., 2014).

\section{KESIMPULAN}

Kayu JUN umur lima tahun tersusun atas serat dengan rata-rata panjang $0,951 \mathrm{~mm}$, diameter $18,8 \mu \mathrm{m}$, dan tebal dinding 3,806 $\mu \mathrm{m}$, serta dengan karakteristik kadar air segar $122,58 \%$, kadar air kering udara 15,25\% dan berat jenis pada kondisi kering udara 0,485. Kelas diameter pohon dan posisi radial kayu berpengaruh signifikan terhadap dimensi serat dan sifat fisik kayu, kecuali pada diameter serat kayu. Tingkat pertumbuhan pohon memiliki korelasi negatif dengan panjang serat, ketebalan dinding serat, kadar air dan berat jenis kering udara, serta memiliki korelasi positif dengan diameter serat dan kadar air segar. Berat jenis kayu berkorelasi positif dengan panjang serat 
dan tebal dinding serat tetapi berkorelasi negatif dengan diameter serat. Menurut pola sifat kayu pada arah radial, kayu JUN yang dipanen pada usia lima tahun masih termasuk kayu juvenil. Kayu ini bisa digunakan sebagai bahan baku mebel dan konstruksi ringan dengan perlakuan pengawetan, tetapi kurang sesuai untuk bahan konstruksi berat.

\section{UCAPAN TERIMA KASIH}

Penulis mengucapkan terima kasih kepada Kepala Kesatuan Kehutanan Daerah Istimewa Yogyakarta yang memberikan izin untuk memanen sembilan pohon jati. Ucapan terima kasih juga disampaikan atas dukungan keuangan untuk penelitian oleh Direktorat Riset dan Pengabdian Masyarakat Direktorat Jendral Penguatan Riset, Teknologi dan Pendidikan Tinggi dengan nomor perjanjian 060 / HB-LIT / IV / 2017, serta Komite Lokakarya dan Klinik untuk Meningkatkan Kualitas Penelitian, Kapasitas Penelitian, Program Penelitian 6-8 November 2017 atas bantuan teknik penulisan artikel publikasi.

\section{DAFTAR PUSTAKA}

Anish, M. C., Anoop, E. V., Vishnu, R., Sreejith, B., \& C.M., J. (2015). Effect of growth rate on wood quality of teak (Tectona grandis L. f.): A comparative study of teak grown under differing site quality conditions. Journal of the Indian Academy of Wood Science, 12, 81-88.

Arce, N., \& Moya, R. (2015). Wood characterization of adult clones of Tectona grandis growing in Costa Rica. Cerne, 21(3), 253-362.

Basri, E., \& Wahyudi, I. (2013). Sifat dasar kayu jati plus perhutani dari berbagai umur dan kaitannya dengan sifat dan kualitas pengeringan. Jurnal Penelitian Hasil Hutan, 31(2), 93-102.

Bhat, K., Priya, P., \& Rugmini, P. (2001). Characterization of juvenile wood in teak. Wood Science and Technology, 34, 517-532.

British-Standard. (1957). Methods of testing small clear specimens of timber. British Standards Institution.

Cardoso, S., Sousa, V. B., Quilhó, T., \& Pereira, H. (2015). Anatomical variation of teakwood from unmanaged mature plantations in East Timor. Journal of Wood Science, 61(3), 326-
333.

Efhamisisi, D., Karimi, A. N., Pourtahmasi, K., \& Asadi, F. (2016). The relationships between fiber dimensions and growth rate in Populus nigra. Journal of Wood and Forest Science and Technology, 23(2), 169-13.

Fo, M., \& Roque, R. (2007). Wood density and fiber dimensions of "Gmelina arborea" in fast growth trees in Costa Rica: relation to the growth rate. Investigación Agraria Sistemas y Recursos Forestales, 16(3), 267-276.

Fujiwara, S., Takamura, N., Sameshima, K., \& Kuroda, K. (1991). Anatomy and properties of Japanese hardwoods I. Variation of fibre dimensions and tissue proportions and their relation to basic density. IAWA Journal, 12, 419-424.

Glass, S. V., \& Zelinka, S. L. (2010). Moisture relations and physical properties of wood in wood handbook: Wood as an engineering material. United States Department of Agriculture - Forest Service - Forest Products Laboratory, Madison.

Gryc, V., Vavrcik, H., \& Horn, K. (2011). Density of juvenile and mature wood of selected coniferous species. Journal of Forest Science, 57(3), 123-130.

Haroen, W. K. (2017). Hubungan berat jenis kayu daun terhadap serat dan kualitas pulp. Jurnal Seluosa, 5(2), 59-68.

Herritsch. (2007). Investigations on wood stability and related properties of radiata pine [University of Canterbury]. https://core.ac.uk/download/pdf/35458628.pdf

Hidayati, F., Ishiguri, F., Iizuka, K., Makino, K., Marsoem, S. N., \& Yokota, S. (2014). Amongclone variations of anatomical characteristics and wood properties in Tectona grandis planted in Indonesia. Wood and Fiber Science, 46, 385-393.

IAWA. (2008). IAWA list of microscope features for hardwood identification. Center for Forest Product Research and Development.

Jayawardana, D., \& Amarasekera, H. (2009). Effect of growth rate on wood quality of teak (Tectona grandis Lf) plantations at Malsiripura, Kurunegala, Sri Lanka. Vidyodaya Jounal of Humanities and Social Science Joint Golden Jubilee Issue of Vidyodaya, 149-170.

Jha, K. K. (2016). What should be the rotation age and harvest management in teak. Indian Forest Journal, 142(4), 309-316.

Karlinasari, L., Andini, S., Worabai, D., Prijanto, P., Budi, S. W., \& Siregar, I. (2018). Tree growth 
performance and estimation of wood quality in plantation trials for Maesopsis eminii and Shorea spp. Journal of Forestry Research, 29, 1157-1166.

Kiaei, M., Naji, H. R., Abdul-Hamid, H., \& Farsi, M. (2016). Radial variation of fiber dimensions, annual ring width, and wood density from natural and plantation trees of alder (Alnus glutinosa) wood. Wood Research Journal, 61(1), 55-64.

Kojima, M., Yamamoto, H., Marsoem, S. N., Okuyama, T., Yoshida, M., Nakai, T., \& Arizono, T. (2009). Effects of the lateral growth rate on wood quality of Gmelina arborea from 3.5-, 7- and 12-year-old plantations. Annals of Forest Science, 66(5), 502-507.

Kojima, M., Yamamoto, H., Okumura, K., Ojio, Y., Yoshida, M., Okuyama, T., \& Hadi, Y. (2009). Effect of the lateral growth rate on wood properties in fast-growing hardwood species. Journal of Wood Science, 55(6), 417-424.

Lachenbruch, B., Moore, J. R., \& Evans, R. (2011). Radial variations in wood structures and functions in woody plants, and hypotheses for its occurrence. In: Meinzer FC, Lachenbruch B \& Dawson TE (eds.), Size and age-related changes in tree structure and function. Tree Physiology, 4, 121-164.

Lacret, R., Varela, R. M., Molinillo, J. M. G., Nogueiras, C., \& Macias, F. A. (2012). Tectonoelins, ew or lignans from a bioactive extract of Tectona grandis. Phytochemistry Letters, 5, 382-385.

Lukmandaru, G. (2011). Variability in the natural termite resistance of plantation teak wood and its relationship with wood extractive content and color properties. Indonesian Journal of Forestry Research, 8(1), 17-31.

Malik, M. F. E. I., \& Abdelgadir, A. Y. (2015). Effect of growth rate on wood density of Eucalyptus camaldulensis wood of coppice origin grown in White Nile State Sudan. Journal of Forest Products and Industries, 4(3), 86-93.

Marsoem, S. N., Prasetyo, V., Sulistyo, J., Sudaryono, \& Lukmandaru, G. (2014). Studi mutu kayu jati di hutan rakyat Gunungkidul III. Sifat fisika kayu. Jurnal Ilmu Kehutanan, $8(2), 75-88$.

Missanjo, E., \& Matsumura, J. (2016). Radial variation in tracheid length and growth ring width of Pinus kesiya Royle ex Gordon in Malawi. International Journal of Research in Agriculture and Forestry, 3(1), 13-21.
Mohamad, S., \& Marsoem, S. N. (2007). Characteristics and variations in physical properties of Acacia mangium Wild wood at some distance and axial-radial position. Jurnal Pemuliaan Tanaman Hutan, 1(1), 1-13.

Mugasha, W. A., Bollandsås, O. M., \& Eid, T. (2013). Relationships between diameter and height of trees in natural tropical forest in Tanzania. A Journal of Forest Science, 75(4), 221-237.

Naji, H. R., Sahri, M. H., Nobuchi1, T., \& Bakar, E. S. (2012). The effect of growth rate on wood density and anatomical characteristics of rubberwood (Hevea brasiliensis Muell. Arg.) in two different clonal trails. Journal of Natural Product and Plant Resources, 1(2), 71-80.

Panshin, A., \& de Zeeuw, C. (1980). Text book of wood technology. Structure identification. Properties and use of the comercial wood of the United States and Canada. Mc. Graw-Hill Book Company.

Perhutani-A. (2019). Statistik Perum Perhutani tahun 2014-2018. https://perhutani.co.id

Perhutani-B. (2019). Perhutani memacu tanaman biomassa. Perum Perhutani.

Pertiwi, Y. A. B., Aiso, H., Ishiguri, F., Wedatama, S., Marsoem, S. N., Ohshima, J., \& Yokota, S. (2017). Effect of radial growth rate on wood properties of Neolamarckia cadamba. Journal of Tropical Forest Science, 29(1), 30-36.

Rizanti, D. E., Darmawan, W., George, B., Merlin, A., Dumarcay, S., Chapuis, H., \& Gerardin, P. (2018). Comparison of teak wood properties according to forest management: short versus long rotation. Annals of Forest Science, 75(39).

Shmulsky, R., \& Jones, P. D. (2019). Forest products and wood science. An Introduction. A John Wiley \& Sons, Inc.

Shukla, S. R., \& Viswanath, S. (2014). Comparative study on growth, wood quality and financial returns of teak (Tectona grandis L.f.) managed under three different agroforestry practices. Agroforestry System, 88(2), 331-341.

Sugiyono. (2013). Metode penelitian kuantitatif, kualitatif dan $R \& D$. C.V. Alfabeta.

Sumida, A., Miyaura, T., \& Torii, H. (2013). Relationships of tree height and diameter at breast height revisited: analyses of stem growth using 20-year data of an even-aged Chamaecyparis obtusa stand. Tree Physiology, 33, 106-118.

Wahyudi, I., \& Arifien, A. F. (2005). Perbandingan struktur anatomis, sifat fisis dan sifat mekanis 
kayu jati unggul dan kayu jati konvensional. Jurnal Ilmu Teknologi Kayu Tropika, 3(2), 5359.

Wahyudi, I., Priadi, T., \& Rahayu, I. S. (2014). Karakteristik dan sifat-sifat dasar kayu jati unggul umur 4 dan 5 tahun asal Jawa Barat. Jurnal Ilmu Pertanian Indonesia, 19(1), 5056.

Yudhanto, \& Sulistyo, J. (2013). Dimensi serat dan sifat fisika kayu Shorea macroptera dan Shorea retusa yang tumbuh di Kalimantan Timur [Universitas Gadjah Mada]. http://etd.repository.ugm.ac.id/penelitian/detail

\section{4}

Zahabu, E., Raphael, T., Chamshama, S. A. O., Iddi, S., \& Malimbwi, R. E. (2015). Effect of spacing regimes on growth, yield, and wood properties of Tectona grandis at Longuza forest plantation, Tanzania. International Journal of Forestry Research, 26(3), 1-16.

Zieminska, K., Butler, D., Gleason, S. M., Wright, I. J., \& Mark, W. (2014). Fibre wall and lumen fractions drive wood density variation across 24 Australian angiosperms. Annals of Botany, $5,1-14$. 
J urnal Pemuliaan Tanaman Hutan

Vol. 13 No. 1, Juni 2020, p. 9 - 19 